American Journal of Applied Sciences 8 (8): 804-809, 2011

ISSN 1546-9239

(C) 2011 Science Publications

\title{
Transesterification of Palm Oil for the Production of Biodiesel
}

\author{
${ }^{1}$ Khalizani Khalid and ${ }^{2}$ Khalisanni Khalid \\ ${ }^{1}$ Department of Human Resource Management, Faculty of Business Administration, \\ University Technology MARA, Kampus Seri Iskandar, \\ 32610 Bandar Baru Seri Iskandar, Perak, Malaysia \\ ${ }^{2}$ Department of Applied Chemistry, Faculty of Applied Sciences, \\ University Technology MARA, 40450 Shah Alam, Selangor, Malaysia
}

\begin{abstract}
Problem statement: Palm oil is known as an important source of edible oil with significant values of renewable energy. Depletion of petroleum had captured much attention on producing biodiesel from the palm oil. Approach: The most concerning methods for the production of biodiesel were discussed, namely transesterification (alkali and acid), enzymetic approach and supercritical alcohol. Results: The results showed the vis-à-vis of the methods for possible consideration of research. Conclusion: Concerning the importance of this vegetable oil, the contribution of palm oil towards diminution of fossil fuel, possible methods for the production of biodiesel and the opportunity for the futures is very much important.
\end{abstract}

Key words: Supercritical alcohol, significant values, possible methods, vegetable oils, catalytic process, fossil fuel, hectare per, low volatility, potential vegetable

\section{INTRODUCTION}

One of the most promising alternative fuels is vegetable oils and their derivatives such as biodiesel (Zubir and Chin, 2010). Vegetable oils including palm oil have been used directly as diesel fuel substitutes. Biodiesel can be made either from vegetable oil (palm oil, coconut oil, castor oil, silk cotton seed oil, jathropa oil) or animal fat. Based on few criteria, palm oil (Elais Guineensis) is the most potential vegetable oil which can be used as raw material to manufacture biodieseland on the other hand the usage of crude palm oil is also meant to anticipate oversupply (Jayed et al., 2009). These efforts have shown that all the vegetable oils tested can be used as fuel with some reservations. The most detrimental properties of these oils are their high viscosity, low volatility, poor atomization and auto-oxidation (Paul et al., 2009).

The golden crop of Malaysia, oil palm, is regarded as the most cost effective vegetable oil crop with average yields of 3.5-5.0 tonnes of palm oil per hectare per year. Thus, it offers a potential environmental friendly alternative fuel source. As biodiesel is gaining considerable global attention and market, standards are vital for its commercialization and market introduction. It is necessary for the authorities to evaluate the safety risk and environmental impact, while giving quality assurance to the users. There is an increasing campaign for cleaner burning fuel in order to safeguard the environment and protect man from the inhalation of genotoxic substances. The exhaust from petroleum products, especially diesel is known to be toxic and carcinogenous in nature, since they contain polycyclic aromatic hydrocarbons. Apart from these reasons, there has also been a surge in the prices of petroleum products worldwide and it is doubtful if these prices would ever again down-plunge since their rising trend has been consistent since late 2004 (Aqeel et al., 2011).

Biodiesel, meanwhile, is an alternative or additive to standard diesel fuel that is made from biological ingredients instead of petroleum. Biodiesel is usually made of bio oils through a series of chemical reactions but is non-toxic and renewable. There are a few different ways to make biodiesel, but most manufacturing facilities in the world produce industrial biodiesel through a process called transesterification, because it easier and saving. In this process, the fat or oil is first purified and then reacted with an alcohol, usually methanol $\left(\mathrm{CH}_{3} \mathrm{OH}\right)$ or ethanol $\left(\mathrm{CH}_{3} \mathrm{CH}_{2} \mathrm{OH}\right)$, in the presence of a catalyst such as potassium hydroxide $(\mathrm{KOH})$ or sodium hydroxide $(\mathrm{NaOH})$. When this happens, the triacylglycerol (oil or fat) is transformed to form esters and glycerol. The esters that remain are called biodiesel (Ghanei et al., 2011; Sylvain et al., 2009; Mário and José, 2011).

Biodiesel blend is the blend of petroleum diesel and biodiesel (methyl ester). A blend of 5\% biodiesel

Corresponding Author: Khalizani Khalid, Faculty of Business Administration, University Technology MARA, Kampus Seri Iskandar, 32610 Bandar Baru Seri Iskandar, Perak, Malaysia 
Am. J. Applied Sci., 8 (8): 804-809, 2011

and 95\% regular diesel is called a B5 blend. Biodiesel has similar physical characteristic as diesel oiland in addition it is a renewable energy and safe for the environment. Biodiesel can be used easily because it can be mixed at any proportion with diesel oil, hence enabling us to apply it immediately for diesel engines that are available without much modification; easy biodegradability; 10 times less poisonous compared to the ordinary diesel oil, the waste product is not black, less sulphur and other aromatic contents, hence the combustion emission produced is safe for environment and perform less accumulation of carbon dioxide gas in atmosphere thus lessen furthermore global heating effect (Abdullah et al., 2009; Christian et al., 2009; Sérgio and Graciela, 2006; Lìlian et al.,2008; Haseeb et al., 2011; Cumali et al., 2011 ).

\section{MATERIALS AND METHODS}

Transesterification process are divided as follows; alkali/ base catalyst, acid catalyst, enzymatic (lipase) and supercritical alcohol process. In all cases, the triglycerides (palm oil) is used as raw materials for the production of biodiesel.

\section{RESULTS}

For a basic catalyst, either sodium hydroxide $(\mathrm{NaOH})$ or potassium hydroxide $(\mathrm{KOH})$ should be used with methanol or ethanol as well as any kind of oils, refine, crude or frying (Rajesh and Jeffrey, 2011; Kai et al., 2010; Khalisanni et al., 2008). In this process it is better to produce the alcoxy before the reaction to obtain a better global efficiency (Fig. 1).

Acid catalyst transesterification is the second conventional way of making the biodiesel. The idea is to use the triglycerides with alcohol and instead of a base to use an acid; the most commonly used is sulfuric acid, sulfonic acid or solid acid catalyst (Shigeki et al., 2011; Siddharth and Sharma, 2010) This type of catalyst gives very high yield in esters but the reaction is very slow, requiring almost always more than one day finishing (Fig. 2).

In the presence of enzyme catalyst, the triglycerides will be converted to methyl ester. The lipase can be secreted from Candida spp. or readily available in the market.

Supercritical alcohols method $\left(>200^{\circ} \mathrm{C}\right)$ has several advantages over that of catalytic process, including high production efficiency and environmentally friendliness. Supercritical fluid transesterification does not require catalysts, therefore, the neutralization, washingand drying steps can be omitted from the process in comparing with conventional biodiesel production process (Fig. 3).

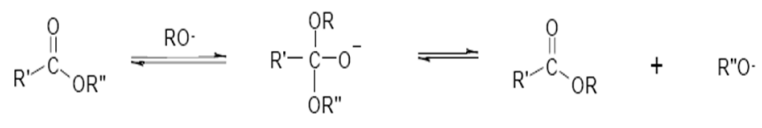

Fig. 1: Mechanism of alkali alcoholysis

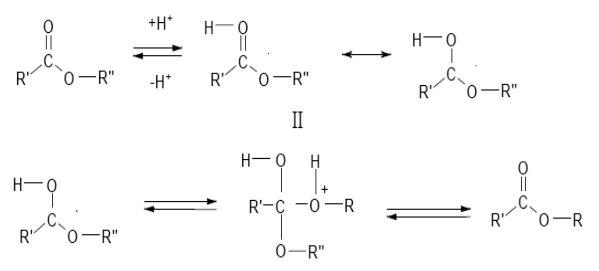

Fig. 2: Mechanism of acid alcoholysis

\section{DISCUSSION}

For basic catalyst, the alcohol-oil molar ratio that should be used varies from $\mathrm{N}=1: 1-6: 1$. However $\mathrm{N}=6: 1$ is the most used ratio giving an important conversion for the alkali catalyst without using a great amount of alcohol. The types of alcohol are usually methanol and ethanol. The last one has fewer safety problems because it is less toxic. The oils used could come from any vegetable, e.g., corn, canola, peanut, sunflower, soybean, olive, palm, palm kernel. As you may see there are quite a few sources that can be used as raw material and all of them are equally relevant only consideration is in the choice is which has lower price on the market. The amount of catalyst that should be added to the reactor varies from $0.5-1 \% \mathrm{w} / \mathrm{w}$, but some authors prefer advice any values between $0.005-0.35 \%$ w/w should be used. The last but not least important variable is the reaction temperature. The standard value for the reaction to take place is $60^{\circ} \mathrm{C}$, but depending on the type of catalyst different temperatures will give different degrees of conversionand for that reason the temperature range should be from $25-120^{\circ} \mathrm{C}$. The reason why there is a great interest in the alkali process is it is more efficient and less corrosive than the acid process, making it a preferred catalyst to be used in industries (Zahir et al., 2011; Oguzhan, 2011; Siddharth et al., 2011; Ruzaimah et al., 2011; Mi et al., 2011).

The limits of this technology are due to the sensitivity that this process has to purity of reactants, to the fatty acid, as well as to the water concentration of the sample. If too much water, it increase the risk of making some soap instead of the desired product. If soap is the end product, a consummation of the reactive will take place and the formation of an emulsion, which makes downstream recovery and purification very difficult and expensive. A normal amount of free fatty acid on the waste cooking oils is about $2 \% \mathrm{w} / \mathrm{w}$. If the 
amount is big, it is recommend a pretreatment via esterification with alcohol and sulfuric acid. After this, the normal alkali process should be continued (Ritesh et al., 2011; Romain et al., 2011; Sivakumar et al., 2011).

Acid-catalyzed transesterification is more suitable for waste or unrefined oil. The process has not gained as much attention as the base-catalyzed transesterification because of the slower reaction rate and the very high methanol to oil molar ratio requirements. The two-step biodiesel process addressed this issue by using an acid catalyst followed by a normal base-catalyzed transesterification. Compared with homogeneous catalysts such as $\mathrm{NaOH}$, the conditions of acid catalyzed transesterification also make the process impractical and uneconomical. Therefore, a process for the conversion of fatty acids and triglycerides to the corresponding ester in a manner that is mild, fast, convenientand universally applicable is required (Habib et al., 2008; Hyunjoo et al., 2003; Dennis et al., 2010; Dora et al., 2007; Xiaoling et al., 2009). Lipases are enzymes used to catalyze some reaction such as hydrolysis of glycerol, alcoholysis and acidolysis, but it has been discovered that they can be used as catalyst for tranesterification and esterification reactions too.

Biocompatibility, biodegradability and environmental acceptability of the biotechnical procedure are the desired properties in agricultural and medical applications. The extra cellular and the intracellular lipases are also able to catalyze the transesterification of triglycerides effectively (Andreina et al., 2011; Giovana et al., 2011; Ríos et al., 2011; Junmin et al., 2011; Shiva and Patrick, 2011).

Advantages of using lipases:

- Possibility of regeneration and reuse of the immobilized residue, because it can be left in the reactor with the ingredients flowing continuously

- Use of high concentration of enzyme prolongs the activation of the lipases

- A bigger thermal stability of the enzyme due to the native state

- Immobilization of lipase could protect it from the solvent that could be used in the reaction and that will prevent all the enzyme particles getting together

- Separation of product will be easier using this catalyst

Disadvantages of using lipases:

- Lost of some initial activity due to volume of the oil molecule
- Number of support enzyme is not uniform

- Biocatalyst is more expensive that the natural enzyme

In supercritical alcohol method, large energy consumed to perform the transesterification process with supercritical alcohols is compensated by more high reaction rate and no requirement of additional clean stages. Finally, this has lead to general reduction of production prime cost by $10-15 \%$ in comparing with catalytic method. The advantage of this method is that FFA present in the oil could be simultaneously esterified in supercritical methanol. These methods allow reaching the conversion value up to $100 \%$, however this caused the increasing of the cost of electrical energy and capital cost (increasing the size of the reactor). Therefore, the method of solubility increasing of the oil in methanol without using the catalytic is needed (Ayhan, 2009; Masafumi et al., 2010; Alessandro et al., 2011).

The properties of biodiesel depend very much on the nature of its raw material as well as the technology or process used for its production. In this respect, the aforementioned standards have specified relevant parameters to govern the quality of biodiesel. Inherent properties from vegetable oils or animal fats that have an effect on the performance of biodiesel as diesel substitute, such as Iodine Value (IV), density, viscosity, cetane number, copper strip corrosion, linolenic acid methyl esters content, polyunsaturated (more or having four double bonds) methyl esters content and phosphorus content, have been included. On the other hand, the properties of biodiesel related to the production technology are, namely, the contents of ester, sulphated ash, water, partial glycerides (mono-, di- and tri-glycerides), alkali, free and total glycerol, flash point and the acid value (Karl et al., 2007; Scott et al., 2010).

\section{CONCLUSION}

Exhaust of biofuel gas emission of the engines much cleaner with reduction $\mathrm{CO}, \mathrm{CO}_{2}, \mathrm{NO}_{\mathrm{x}}, \mathrm{SO}_{2}$ and so the opacity, therefore it is more environmentally friendly. The commercial production of biodiesel is still at its primary stage. Brief comparison between several potential methods for the production of methyl ester gives are significance to cut cost of production and lowering risk of procedure deficiencies. Transesterification process by using alkali catalyst was believed the most promising and productive methyl ester production method for current period. 
Am. J. Applied Sci., 8 (8): 804-809, 2011

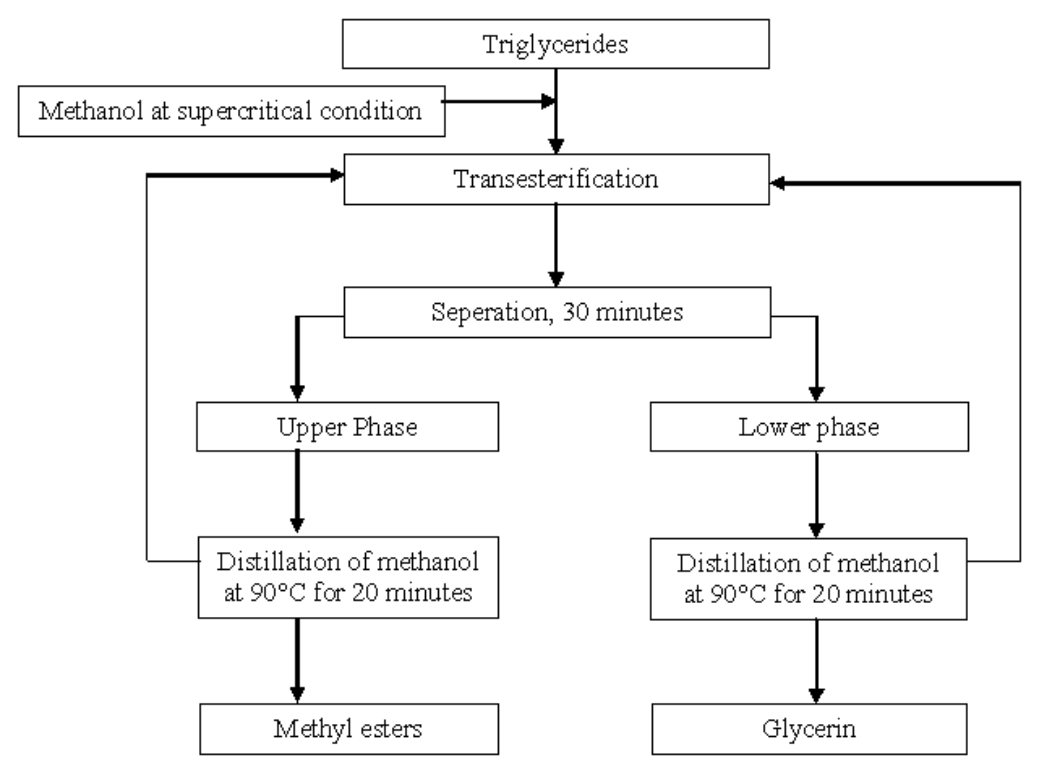

Fig. 3: Process flow diagram for biodiesel production using supercritical methanol

Regardless the production of saponified compound as by products, this method is reliable because the retention of methyl ester stability compared to supercritical alcohol process. At $400^{\circ} \mathrm{C}$, methyl ester which produced from palm oil will loss stability, because palm oil rich with palmitic and oleic fatty acids which the boiling point of this compounds is about $400^{\circ} \mathrm{C}$. Acid catalyst are also potential to be used for methyl ester production process in industries but the process produced more water than alkali catalyst while the use of lipase enzyme for fatty acids esterification is very relatively costly.

\section{REFERENCES}

Abdullah, A.Z., B. Salamatinia, H. Mootabadi and S. Bhatia, 2009. Current status and policies on biodiesel industry in Malaysia as the world's leading producer of palm oil. Energy Policy, 37: 5440-5448. DOI: 10.1016/j.enpol.2009.08.012

Alessandro, G., S. Onofrio and T. Emanuele, 2011. Transesterification of rapeseed oil over acid resins promoted by supercritical carbon dioxide, J. Supercrit. Fluids, 56: 186-193. DOI: 10.1016/j.supflu.2010.12.005

Andreina, A., F. Marco, F.L. Gloria, M.P. Jose and M.G. Jose, 2011. Kinetically controlled synthesis of monoglyceryl esters from chiral and prochiral acids methyl esters catalyzed by immobilized Rhizomисor miehei lipase. Bioresource Technol., 102: 507-512. DOI: 10.1016/j.biortech.2010.08.095
Aqeel, A.B., Z. Gholamreza and H. Haslenda, 2011. Progress and challenges in utilization of palm oil biomass as fuel for decentralized electricity generation. Renew. Sustain. Energy Rev., 15: 574583. DOI: 10.1016/j.rser.2010.09.031

Ayhan, D., 2009. Biodiesel from waste cooking oil via base-catalytic and supercritical methanol transesterification. Energy Conver. Manage., 50: 923-927. DOI: 10.1016/j.enconman.2008.12.023

Christian, R.C., A. deC. J.R. João and L.S. José, 2009. Biodiesel $\mathrm{CO}_{2}$ emissions: A comparison with the main fuels in the Brazilian market. Fuel Process. Technol., 90: 204-211. DOI: 10.1016/j.fuproc.2008.09.006

Cumali, I., A. Selman, B. Rasim and A. Hüseyin, 2011. Biodiesel from safflower oil and its application in a diesel engine. Fuel Process. Technol., 92: 356-362. DOI: 10.1016/j.fuproc.2010.09.028

Dennis, Y.C.L., W. Xuan and M.K.H. Leung, 2010. A review on biodiesel production using catalyzed transesterification. Appl. Energy, 87: 1083-1095. DOI: 10.1016/j.apenergy.2009.10.006

Dora, E.L., G.G. Jr. James and A.B. David, 2007. Transesterification of triacetin with methanol on Nafion ${ }^{\circledR}$ acid resins. J. Catal., 245: 381-391. DOI: 10.1016/j.jcat.2006.10.027

Ghanei, R., G.R. Moradi, R. Taherpour Kalantari and E. Arjmandzadeh, 2011. Variation of physical properties during transesterification of sunflower oil to biodiesel as an approach to predict reaction progress. Fuel Process. Technol., 92: 1593-1598. DOI: 10.1016/j.fuproc.2011.04.003 
Giovana, C., C. da, S. Patrícia, L. Lindomar and J.O. Vladimir et al., 2011. Ultrasound-assisted enzymatic transesterification of methyl benzoate and glycerol to 1-glyceryl benzoate in organic solvent. Enzyme Microb. Technol., 48: 169-174. DOI: $10.1016 / j$.enzmictec.2010.10.004

Habib, F., I. Nasser and F. Soghra, 2008. Solid trichlorotitanium (IV) trifluoromethanesulfonate $\mathrm{TiCl}_{3}$ (OTf) catalyzed efficient acylation of $-\mathrm{OH}$ and -SH: Direct esterification of alcohols with carboxylic acids and transesterification of alcohols with esters under neat conditions. J. Mol. Catal. AChem., 289: 61-68. DOI: 10.1016/j.molcata.2008.04.010

Haseeb, A.S.M.A., M.A. Fazal, M.I. Jahirul and H.H. Masjuki, 2011. Compatibility of automotive materials in biodiesel: A review. Fuel, 90: 922-931. DOI: 10.1016/j.fuel.2010.10.042

Hyunjoo, L., J.K. Sung, S.A. Byoung, K.L. Won and S.K. Hoon, 2003. Role of sulfonic acids in the Sncatalyzed transesterification of dimethyl carbonate with phenol. Catal. Today, 87: 139-144. DOI: 10.1016/j.cattod.2003.09.005

Jayed, M.H., H.H. Masjuki, R. Saidur, M.A. Kalam and M.I. Jahirul, 2009. Environmental aspects and challenges of oilseed produced biodiesel in Southeast Asia. Renew. Sustain. Energy Rev., 13: 2452-2462. DOI: 10.1016/j.rser.2009.06.023

Junmin, D., H. Xianglin, H.W. Dong and F. Cuiping, 2011. Rapid and efficient gas chromatographic method for measuring the kinetics of lipasecatalyzed transesterification of phosphatidylcholine. J. Mol. Catal. B: Enzym, 69: 103-106. DOI: 10.1016/j.molcatb.2011.01.002

Kai, T., Y. Mataki, T. Nakazato and H. Takanashi, 2010. Reaction conditions of two-step batch operation for biodiesel fuel production from used vegetable oils. J. Applied Sci., 10: 1171-1175.

Karl, R., Q. Robert, B. Joe, L. Hu and D. Basil et al., 2007. Real-world comparison of probe vehicle emissions and fuel consumption using diesel and 5\% biodiesel (B5) blend. Sci. Total Environ., 376: 267-284. DOI: 10.1016/j.scitotenv.2006.11.021

Khalisanni, K., K. Khalizani, M.S. Rohani and P.O. Khalid, 2008. Analysis of Waste Cooking Oil as Raw Material for Biofuel Production. Global J. Environ. $\quad$ Res. 2(2):81-83. http://idosi.org/gjer/gjer2(2)08/4.pdf

Lìlian, L.N.G., A.P.P. Pedro, A.T. Ednildo, O.R. Gisele and B.A. Jailson, 2008. Carbonyl compounds emitted by a diesel engine fuelled with diesel and biodiesel-diesel blends: Sampling optimization and emissions profile. Atmos. Environ., 42: 8211-8218. DOI: 10.1016/j.atmosenv.2008.07.053
Mário, L.R. and R.S. José, 2011. Exhaust emissions from a diesel powered vehicle fuelled by soybean biodiesel blends (B3-B20) with ethanol as an additive (B20E2-B20E5). Fuel 90: 98-103. DOI: 10.1016/j.fuel.2010.09.010

Masafumi, F., K. Takashi, S. Takashi, M. Tomoko, O. Tsutomu and H. Tadao, 2010. Transesterification of supercritical ethyl acetate by higher alcohol. J. Supercrit. Fluids, 54: 231-236. DOI: 10.1016/j.supflu.2010.04.004

Mi, J.K., K. Mi-Young, O.Z. Kwon and S. Gon, 2011. Transesterification of vegetable oils over a phosphazenium hydroxide catalyst incorporated onto silica. Fuel Process. Technol., 92: 126-131. DOI: 10.1016/j.fuproc.2010.09.015

Oguzhan, I., 2011. Dolomite as a heterogeneous catalyst for transesterification of canola oil. Fuel Process. Technol., 92: 452-455. DOI: 10.1016/j.fuproc.2010.10.009

Paul, U., T. Patricia, T. Julia and B. Philip, 2009. Substitutable biodiesel feedstocks for the UK: A review of sustainability issues with reference to the UK RTFO. J. Clean. Prod., 17: 37-S45. DOI: 10.1016/j.jclepro.2009.04.014

Rajesh, K.B. and P.O. Jeffrey, 2011. Heterogeneous catalytic transesterification of phosphatidylcholine. Bioresource Technol., 102: 1942-1946. DOI: 10.1016/j.biortech.2010.08.040

Ríos, A.P., F.J.H. Fernández, D. Gómez, M. Rubio and G. Víllora, 2011. Biocatalytic transesterification of sunflower and waste cooking oils in ionic liquid media. Process Biochem., 46: 1475-1480. DOI: 10.1016/j.procbio.2011.03.021

Ritesh, K., G.R. Kumar and N. Chandrashekar, 2011. Microwave assisted alkali-catalyzed transesterification of Pongamia pinnata seed oil for biodiesel production. Bioresource Technol., 102: 6617-6620. DOI: 10.1016/j.biortech.2011.03.024

Romain, R., L. Ying, D. Brigitte, T.R. Sophie and P. Laurent, 2011. On-line monitoring of the transesterification reaction between triglycerides and ethanol using near infrared spectroscopy combined with gas chromatography. Bioresource Technol., 102: 6702-6709. DOI: 10.1016/j.biortech.2011.03.111

Ruzaimah, N.M.K., Y. Suzana and R. Umer, 2011. Optimization of polyol ester production by transesterification of Jatropha-based methyl ester with trimethylolpropane using Taguchi design of experiment. Fuel, 90: 2343-2345. DOI: 10.1016/j.fuel.2011.02.018 
Scott, O.S., E.L. Amy, M.B. Melissa, O.C. William and X. Xiaobo, 2010. A comparative analysis of performance and cost metrics associated with a diesel to biodiesel fleet transition. Energy Policy, 38: 7451-7456. DOI: 10.1016/j.enpol.2010.08.031

Sérgio, M.C. and A. Graciela, 2006. Aromatic hydrocarbons emissions in diesel and biodiesel exhaust. Atmos. Environ., 40: 6821-6826. DOI: 10.1016/j.atmosenv.2006.05.068

Shigeki, F., U. Yoshihiro and Y. Hiroshi, 2010. Variables affecting the reactivity of acid-catalyzed transesterification of vegetable oil with methanol. Bioresource Technol., 101: 3325-3332. DOI: 10.1016/j.biortech.2009.12.086

Shiva, S.K. and A. Patrick, 2011. Lipase-catalyzed synthesis and characterization of 1-butanoyl-2palmitoyl phosphatidylcholine, a potential lipidic prodrug of butyric acid. Chem. Phys. Lipids, 164: 246-250. DOI: 10.1016/j.chemphyslip.2011.02.001

Siddharth, J. and M.P. Sharma, 2010. Kinetics of acid base catalyzed transesterification of Jatropha curcas oil. Bioresource Technol., 101: 7701-7706. DOI: 10.1016/j.biortech.2010.05.034

Siddharth, J., M.P. Sharma and R. Shalini, 2011. Acid base catalyzed transesterification kinetics of waste cooking oil. Fuel Process. Technol., 92: 32-38. DOI: 10.1016/j.fuproc.2010.08.017
Sivakumar, P., K. Anbarasu and S. Renganathan, 2011. Bio-diesel production by alkali catalyzed transesterification of dairy waste scum. Fuel 90: 147-151. DOI: 10.1016/j.fuel.2010.08.024

Sylvain, L., N. Karthikeyan, D. Erik, McC. Ian and O. Michael, 2009. Optimizing biodiesel production in India Appl. Energy., 86: 125-131. DOI: 10.1016/j.apenergy.2009.05.024

Xiaoling, M., L. Rongxiu and Y. Hongyan, 2009. Effective acid-catalyzed transesterification for biodiesel production. Energ. Conver. Manage., 50: 2680-2684. DOI: 10.1016/j.enconman.2009.06.021

Zahir, M.D., S. Abdurrahman and O. Gulsen, 2011. Alkali catalyzed transesterification of safflower seed oil assisted by microwave irradiation Fuel Process. Technol., 92: 308-313. DOI: 10.1016/j.fuproc.2010.09.020

Zubir, M.I. and S.Y. Chin, 2010. Kinetics of modified zirconia-catalyzed heterogeneous esterification reaction for biodiesel production. J. Applied Sci., 10: 2584-2589. DOI: 10.3923/jas.2010.2584.2589 